\title{
Analysis of alternative policy instruments to promote electric vehicles in
}

\section{Austria}

\author{
Viktoria Gass $^{1, *}$, Johannes Schmidt ${ }^{1}$, Erwin Schmid ${ }^{1}$ \\ ${ }^{1}$ Department of Economics and Social Sciences, University of Natural Resources and Life Sciences, \\ Feistmantelstrasse 4, A-1180 Vienna, Austria \\ *Corresponding author, Tel: +43 147654 3594, Fax: +43 1476543692,E-mail: v.gass@students.boku.ac.at
}

\begin{abstract}
The large amount of $\mathrm{CO}_{2}$ emissions and of fossil fuel consumption by the transportation sector makes the sector central for attaining the EU energy and climate policy targets. Consequently, new propulsion systems are developed in the automotive industry, which currently have cost disadvantages compared to conventional internal combustion engines (ICE). The article provides a review on support measures for electric vehicles which have been currently implemented within the European Union. In a case study analysis for Austria, we analyze different policy instruments including a $\mathrm{CO}_{2}$ tax aiming to support the introduction of electric vehicles in Austria. We have calculated and compared total costs of ownership (TCO), which includes all costs associated with the ownership of an automobile including costs of purchasing, operating and maintaining, charges and taxes as well as costs of recycling and disposal. A survey on main specifications of electric vehicles has been conducted among the main automobile manufacturers and importers in Austria. Based on this survey, TCO have been calculated dynamically from 2011 to 2020 for a business as usual (BAU) scenario considering currently implemented taxes and subsidies for ICE and electric vehicle systems. Three alternative policy support measures have been assessed to promote EV to ICE until 2015. We conclude that an up-front price support seems to be favorable over taxation systems. The paper focuses only of the effectiveness of the three policy support measures but does not analyze their efficiency.
\end{abstract}

Keywords: Electric vehicles, Total cost of ownership (TCO), Fiscal policy instruments, Break-even

\section{Introduction}

Currently, 98\% of the transportation sector in the EU depends on fossil fuels. The sector is responsible for approx. 21\% of the greenhouse gas (GHG) emissions, with more than half of the emissions produced by passenger cars [1]. The EU Directive (2009/33/EC) on the promotion of clean and energy efficient road transport vehicles has been released to foster a broad market penetration of environmentally-friendly vehicles in order to decarbonize the transportation sector and to reduce oil dependency.

Several new propulsion systems as plug-in hybrids, range extenders as well as electric vehicles have emerged and entered the market or are ready to enter the market in the near future [2]. However, in order to achieve a shift in the transportation sector the cost disadvantages of the newly emerged propulsion systems have to be overcome. Economic viability and a successful introduction of alternative propulsion systems will mainly depend on economic aspects such as relative costs. The gap between the total cost of ownership (TCO) of alternative transportation systems and ICE should be temporarily closed by appropriate policy interventions to promote environmentally-friendly vehicles.

Current research regarding the economic viability of electric vehicles (EV) focused mainly on lifecycle cost analysis [3,4,5]. Thiel et al. [3] compared the well-to-wheel $\mathrm{CO}_{2}$ emissions, costs and $\mathrm{CO}_{2}$ abatement costs of passenger light duty vehicles including gasoline vehicles, diesel vehicles, diesel hybrid vehicles, plug-in hybrid and battery electric vehicles [3]. A static comparison has been conducted for the years 2010, 2020 and 2030 under a new energy policy scenario for Europe. They conclude that electric vehicles can clearly contribute to a decarbonization of the transportation system if renewable electricity is used. According to [3], 
current cost disadvantages of electric vehicles can be overcome by adequate policy support instruments to attain payback periods of less than five years.

Ogden et al. [4] conducted an analysis of the societal lifecycle cost of transportation including the purchase price, fuel costs, externality costs of securing oil supply and damage costs for emissions of air pollutants and greenhouse gases which are calculated over the full fuel cycle. Thomas [5] developed a dynamic computer simulation model that compares the societal benefits of replacing conventional gasoline cars with vehicles that are partially electrified, including hybrid electric vehicles. He concludes that electric vehicles in combination with hybrids, plug-in hybrids and biofuels will be necessary to achieve an $80 \%$ reduction in greenhouse gas emissions below 1990 levels by simultaneously cutting dependence on imported oil and eliminating nearly all controllable urban air pollution from the light duty vehicle fleet. However, to increase market shares, market barriers have to be overcome. Therefore, the consumer perspective and thus effective and efficient policy instruments should be the focus of further research. Taxation systems regarding vehicles vary strongly between countries.

The aim of the article is to analyze different policy instruments by comparing total cost of ownership (TCO) of EV and ICE in Austria. TCO are calculated dynamically from 2011 to 2020 for a business as usual (BAU) scenario considering currently implemented taxes and subsidies for ICE and EV in Austria. In contrast to lifecycle cost analysis of alternative propulsion systems, our analysis focuses mainly on the total cost of ownership and places the consumer perspective in the center of the analysis. The consumer perspective is placed in the center of our analysis as only early adopters are willing to accept the current cost differential between ICE and EV. As such instruments necessary to close the gap are considered to be necessary in order to achieve a mass market introduction.

The article is structured as follows. Section 2 provides an overview of the support schemes currently launched in the EU-15. Section 3 presents the methodology and data. An analysis on different policy support instruments to equalize the TCO of EV and ICE in Austria is shown in Section 4 and section 5 presents major conclusions from our analysis.

\section{Implemented support schemes for $\mathbf{E V}$ in the $\mathbf{E U - 1 5}$}

Many EU member states have introduced national targets for the EV driving stock, the expansion of charging infrastructure, or production targets of electric vehicles [6]. Most EU member states overcome the cost disadvantage of alternative vehicles by introducing policy instruments such as an up-front price support in order to increase the affordability of electric vehicles by reducing the marginal capital cost, which is considered as one of the key barriers for consumers [7]. Within the EU-15, passenger cars have mainly been the target of a tax reform that takes into account the $\mathrm{CO}_{2}$ emissions of vehicles. Policy instruments that are currently implemented in order to stimulate the up-take of alternative propulsion systems consist of [7]:

- Registration or purchase taxes

Registration or purchase taxes are an up-front cost and can have a strong impact on $\mathrm{CO}_{2}$ emissions and the market, if costs are differentiated with regard to the specific $\mathrm{CO}_{2}$ emissions of the vehicles. In France, a bonus/malus system has been introduced whereby vehicles above certain $\mathrm{CO}_{2}$ emission thresholds have to pay a malus and vehicles under the threshold receive a bonus. Such a system may increase the political acceptability as well as of consumers, because it can be designed in a revenue neutral manner [7]. 
- Circulation or motor taxes

Circulation or motor taxes have according to [7] a limited effect on the purchase decision as they are annual or monthly charges. Although they are considered to be politically acceptable, their impact to promote EV is rather low as the cost range of such measures is limited.

- Fuel taxes

Fuel charges have limited short-term effects, because they do not change the purchasing decision of consumers in the longer term [8]. Furthermore, they are considered to be politically prohibitive.

Policy instruments to stimulate the up-take of alternative propulsion systems are subsidies, taxation of benefits in kind and treatment of depreciation (relevant for company cars) and in use and parking charges [8]. Table 1 provides an overview of the currently implemented support measures [7-10].

Table 1: Policy instruments to supporting EV in the EU-15

\begin{tabular}{ll}
\hline Country & Economic instruments for the support of EV \\
\hline Austria & $\begin{array}{l}\text { Exemption from fuel consumption tax } \\
\text { Exemption from monthly vehicle tax }\end{array}$ \\
\hline Belgium & $\begin{array}{l}\text { Purchasers of electric cars receive a personal income tax reduction of 30\% of the } \\
\text { purchase price (with a maximum of EUR 9,000) }\end{array}$ \\
\hline Finland & Exemption of fuel tax \\
\hline Italy & $\begin{array}{l}\text { A tax incentive of EUR800 and a two year exemption from annual circulation tax is } \\
\text { granted for the purchase of a new passenger. }\end{array}$ \\
\hline Denmark & $\begin{array}{l}\text { Exemption from registration tax and annual circulation tax. Further EV qualify for } \\
\text { free parking }\end{array}$ \\
\hline Germany & $\begin{array}{l}\text { EV exempt from the annual road tax for a period of five years from the date of the } \\
\text { first registration }\end{array}$ \\
\hline Spain & $\begin{array}{l}\text { Various regional governments grant tax incentives for the purchase of alternative } \\
\text { fuel vehicles including EV - approx. EUR 6,000 }\end{array}$ \\
\hline France & $\begin{array}{l}\text { Bonus-Malus System; New Cars with CO2 emissions below 125 g/km receive a } \\
\text { premium. EV receive currently EUR 5,000 }\end{array}$ \\
\hline Greece & $\begin{array}{l}\text { EV exempt from registration tax. If engine capacity below 1929 cc, exemption } \\
\text { from road tax. Further EV are even allowed to drive in Athens when parts of the } \\
\text { city are restricted to ICE to reduce traffic congestion. }\end{array}$ \\
\hline Ireland & EV exempt from registration tax - approx. EUR 2,500. \\
\hline The Netherlands & approx. EUR 6,400 reduction from the registration tax \\
\hline Portugal & Exemption from registration tax \\
\hline Sweden & Exemption from annual road tax for a period of 5 years upon first registration \\
\hline United Kingdom & Exemption from annual road tax \\
\hline Ireland & Exemption from registration tax \\
\hline Luxemburg & Annual circulation taxes based on CO C $_{2}$ emissions \\
\hline
\end{tabular}

\section{Data and Methodology}

Total cost of ownership (TCO) includes all costs arising with the ownership of an automobile including costs of purchasing, operating and maintaining, charges and taxes as well as costs of recycling and disposal over a specified timeframe under consideration of opportunity costs. TCO is defined as following:

$$
T C O=-I+\sum_{t=1}^{N} c(1+r)^{-t}+R(1+r)^{-N},
$$


where $I$ represents the purchase price, $c$ maintenance and operating costs, $r$ the discount factor and $R$ the resale price. Maintenance and operating costs include infrastructure charges, insurance, fuel consumption tax (NoVA) and the monthly engine related vehicle tax (motorbezogene Versicherungssteuer).

TCO have been calculated for limited vehicle options based on a survey conducted with the main automobile manufacturers and importers in Austria. The survey includes data on technical specifications and costs. The EVs included in the analysis are either already available for sale or will be in the near future. The survey has been conducted with the automotive offices of Nissan, Peugot, Renault, Mitsubishi and Think City in Austria. The ICE have been chosen of similar size and technical specifications, which are the most often sold cars in the vehicle class [11]. Technology and performance assumptions for ICE have been derived from the respective automobile manufacturers [12,13]. Table 2 provides an overview of the main specifications as well as the main resulting performance and cost figures of EV and ICE for which the TCO have been calculated dynamically over the period 2011 until 2020.

Table 2: Technical, performance and cost assumptions of analyzed vehicles

\begin{tabular}{|c|c|c|c|c|c|}
\hline & $\begin{array}{l}\text { VW Golf } \\
\text { Rabbit }\end{array}$ & $\begin{array}{l}\text { VW Golf } \\
\text { Rabbit }\end{array}$ & Nissan Leaf & $\begin{array}{l}\text { Peugeot } \\
\text { iOn }\end{array}$ & $\begin{array}{l}\text { Mitsubishi } \\
\text { i-Miev }\end{array}$ \\
\hline \multicolumn{6}{|l|}{ Technology } \\
\hline ICE engine displacement (l) & 1.6 & 1.2 & - & - & - \\
\hline Turbocharger (yes/no) & yes & yes & - & - & - \\
\hline PT power $(\mathrm{kW})$ & 77 & 77 & - & - & . \\
\hline Electric motor power $(\mathrm{kW})$ & - & - & 80 & 47 & 49 \\
\hline Battery capacity (kWh) & - & - & 24 & 16 & 16 \\
\hline Energy source & Diesel & Gasoline & Electricity & Electricity & Electricity \\
\hline \multicolumn{6}{|l|}{ Performance } \\
\hline Weight (kg) & 1,314 & 1,314 & 1,545 & 1,120 & 1080 \\
\hline Acceleration 0-100 km/h (in s) & 11.3 & 10.6 & - & - & . \\
\hline Top speed $(\mathrm{km} / \mathrm{h})$ & 190 & 190 & 140 & 130 & 130 \\
\hline Fuel consumption (l/100km) & 4.1 & 5.2 & - & - & - \\
\hline $\begin{array}{l}\text { Electricity consumption } \\
(\mathrm{kWh} / 100 \mathrm{~km})\end{array}$ & - & 0 & 15 & 15 & 15 \\
\hline Tailpipe $\mathrm{CO}_{2}$ emissions (g/km) & 107 & 121 & - & - & - \\
\hline \multicolumn{6}{|l|}{ Costs } \\
\hline $\begin{array}{l}\text { Vehicle incl. VAT and NoVA } \\
\text { (EUR) }\end{array}$ & 20,350 & 22,120 & 39,600 & 36,000 & 35,900 \\
\hline $\begin{array}{l}\text { NoVA (fuel consumption tax in } \\
\% \text { of purchase price) }\end{array}$ & $4 \%$ & $4 \%$ & $0 \%$ & $0 \%$ & $0 \%$ \\
\hline Battery cost (EUR/kWh) & - & - & 600 & 600 & 600 \\
\hline Battery cost (EUR) & - & - & 14,400 & 9,600 & 9,600 \\
\hline Loss in value p.a. & $17 \%$ & $16 \%$ & $32 \%$ & $32 \%$ & $32 \%$ \\
\hline Maintenance cost (EUR/100km) & 4.6 & 4.1 & 2.5 & 2.5 & 2.5 \\
\hline
\end{tabular}

The TCO have been calculated over a period of five years assuming that $15,000 \mathrm{~km}$ are traveled annually. According to the survey, automobile manufacturers expect that the battery of EV needs to be replaced after approx. $75,000 \mathrm{~km}$. We assume that vehicles are sold after 
five years, because no estimates on battery replacement costs are currently available. Both assumptions refer to results of [13] and have been confirmed by the survey. The percentage loss in value p.a. as well as maintenance costs are guesstimates of manufacturers received in the survey. Average figures are applied to all EV, because the guesstimates from the respective manufacturers differ slightly and empirical values are not available yet. We also assume that the purchase price of ICE will not change over time, because further efficiency gains in ICE are costly [2]. Furthermore, learning effects from increased production volumes decrease the purchase price. The learning effects have been depicted from an analysis conducted by [15] and are consistent with $[3,14,16]$. Currently, battery costs amount to approx. $600 \mathrm{EUR} / \mathrm{kWh}$ and shall decrease to approx. $300 \mathrm{EUR} / \mathrm{kWh}$ by 2015 if the projected production volumes are reached. Projected productions volumes are reflected in the assumed learning rate and have not been separately been calculated. As such price reductions resulting from an increase in production volume are already reflected in the calculation of the TCO.

The current gasoline price in Austria amounts to $1.3 \mathrm{EUR} / \mathrm{l}$ and for diesel to $1.1 \mathrm{EUR} / \mathrm{l}$ including taxes and charges. The gasoline and diesel prices are assumed to be consistent with the projected oil prices in the Annual Energy Outlook. The electricity price for Austrian households amounts currently to $0.15 \mathrm{EUR} / \mathrm{kWh}$ including taxes and charges. The average increase in the electricity price (EEX Phelix baseload) from 2000 until now has been approx. $2.8 \%$ p.a. Similar price developments are assumed to 2020.

\section{Results}

The three policy scenarios consist of an up-front price support, a $\mathrm{CO}_{2}$-tax as well as a fuel consumption tax for ICE, respectively. The level of incentive to make EV competitive from 2011 onwards is shown for each policy instrument.

In a BAU-scenario, the EV becomes cost-competitive with ICE in the year 2015. TCO of ICE are increasing over time mainly due to rising fuel costs. The decrease in TCO of EV is mainly attributed to the projected decreases in battery costs. The TCO time line for EV and ICE is shown in Fig. 1.

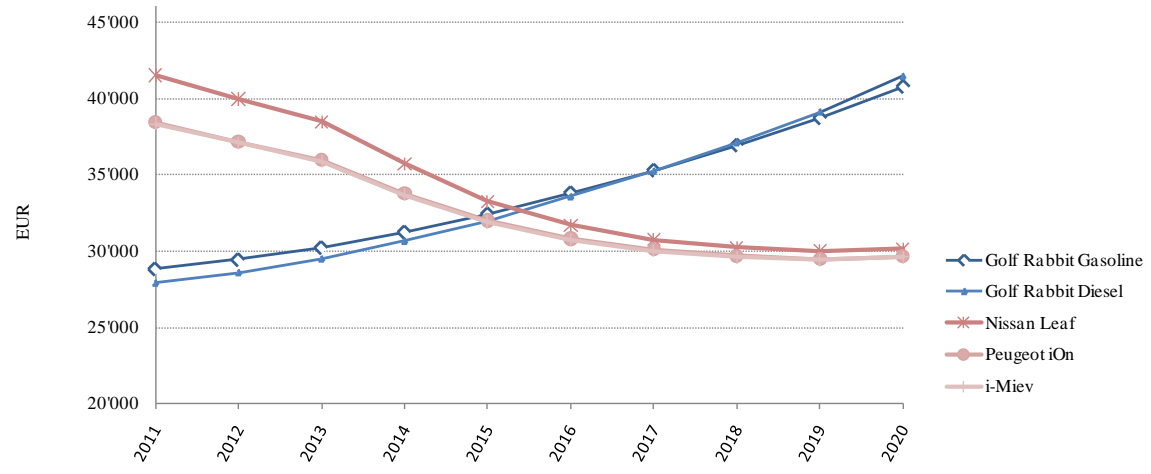

Fig. 1: TCO - BAU-scenario

The BAU scenario implies that TCO of ICE and EV will converge in 2015. However, it only may convergence if the projected volumes are produced to realize the necessary economies of scales. Consequently, subsidies may be necessary to realize the projected production volumes. As shown in Section 2, many countries have currently implemented or are considering to implement an up-front price support (e.g. usually in the form of an exemption of the registration tax) for alternative propulsion systems. An up-front price support is considered as an effective policy instrument, because consumers put much larger emphasis on the purchase 
price of a vehicle than on the resulting maintenance and operating costs [8]. However, by introducing an up-front price support for $\mathrm{EV}$, the question arises of how much price support is necessary to incentivize sufficient uptake of EV.

In our analysis, we have calculated alternative levels of upfront price support to offset the gap between ICE and EV TCO (table 3). It is assumed that covering the entire price differential would require large amounts of subsidies despite remaining technical limitations such as limited range that may lead to higher costs [8]. However, a regressive price support system would minimize windfall profits. Nevertheless, the interviewed representatives of automotive manufacturers clearly stated that final purchase prices are set under consideration of governmental support and that EV will be available for sale only in countries with governmental support measures at a level that is considered sufficient from the perspective of car manufacturers. The level of price support should be adjusted annually to account for learning effects. High political and public acceptability is attributed to an up-front price, however some moral hazard problem will remain [7].

Table 3: Levels of up-front price support until 2015 in Euro

\begin{tabular}{rrrrrr}
\hline & 2011 & 2012 & 2013 & 2014 & 2015 \\
\hline up-front price support & $10^{\prime} 000$ & $8^{\prime} 000$ & $5^{\prime} 500$ & $3^{\prime} 000$ & 0 \\
\hline
\end{tabular}

In a second scenario, we have analyzed the level of a $\mathrm{CO}_{2}$ tax for the transportation sector in order to promote $\mathrm{EV}$. A CO $\mathrm{CO}_{2}$-tax is generally considered to be an effective policy instrument from an environmental point of view, because it contributes to lowering $\mathrm{CO}_{2}$ emissions. Furthermore, it is a cost-effective policy instrument as it generates revenues for the government that can be used to subsidize cleaner technologies [18]. Besides reducing greenhouse gas emissions, a $\mathrm{CO}_{2}$-tax has the capacity to reduce other external costs of ICE such as changing driving habits, reducing traffic congestions and other emissions e.g. fine dust [18].

A $\mathrm{CO}_{2}$ tax can be levied by directly taxing gasoline and diesel corresponding to the carbon content of the respective fuel. This implies that a $\mathrm{CO}_{2}$ tax would result in an increase in the respective fuel price. The level of $\mathrm{CO}_{2}$ price necessary to sufficiently promote $\mathrm{EV}$ is shown in Table 4 and Table 5 shows the resulting gasoline and diesel prices.

In our analysis, the implementation of a $\mathrm{CO}_{2}$ tax becomes effective, if the $\mathrm{CO}_{2}$ price is approx. 2'000 EUR/t. Currently, the $\mathrm{CO}_{2}$ price on the EU Emission Allowances spot market trades at $15 \mathrm{EUR} / \mathrm{t}$. Increasing the $\mathrm{CO}_{2}$ tax to up to 2'000 EUR/t is seen as politically infeasible. Therefore, the introduction of a $\mathrm{CO}_{2}$ tax as sole policy instrument to reduce the price differential and to achieve a certain market penetration of EV is not considered viable. 
Table 4: Required levels of $\mathrm{CO}_{2}$ tax until 2015 in EUR/t

\begin{tabular}{rrrrrr}
\hline & 2011 & 2012 & 2013 & 2014 & 2015 \\
\hline $\mathrm{CO}_{2}$ tax & $2 ' 500$ & $2 ' 300$ & $2 ' 250$ & $1 ' 000$ & 0 \\
\hline
\end{tabular}

Table 5: Resulting gasoline and diesel prices until 2015

\begin{tabular}{lrrrrr}
\hline & 2011 & 2012 & 2013 & 2014 & 2015 \\
\hline Golf Rabbit Gasoline & & & & & \\
$\mathrm{CO}_{2}$ emission g/km & 121 & 121 & 121 & 121 & 121 \\
Fuel consumption l/ km & 0.052 & 0.052 & 0.052 & 0.052 & 0.052 \\
$\mathrm{CO}_{2}$ emission g/l & $2^{\prime} 327$ & $2^{\prime} 327$ & $2^{\prime} 327$ & $2^{\prime} 327$ & $2^{\prime} 327$ \\
$\mathrm{CO}_{2}$ tax ct/g & 0.250 & 0.230 & 0.225 & 0.100 & 0.050 \\
\hline $\mathrm{ct} / \mathrm{l}$ & 581.7 & 535.2 & 523.6 & 232.7 & 116.3 \\
$\mathrm{Golf} \mathrm{Rabbit} \mathrm{Diesel}_{\mathrm{CO}_{2} \text { emission g/km }}$ & 107 & 107 & 107 & 107 & 107 \\
Fuel consumption l/ km & 0.041 & 0.041 & 0.041 & 0.041 & 0.041 \\
$\mathrm{CO}_{2}$ emission g/l & $2{ }^{\prime} 610$ & $2^{\prime} 610$ & $2^{\prime} 610$ & $2 ' 610$ & $2 ' 610$ \\
$\mathrm{CO}_{2}$ tax ct/g & 0.250 & 0.230 & 0.225 & 0.100 & 0.050 \\
\hline $\mathrm{ct} / \mathrm{l}$ & 652.4 & 600.2 & 587.2 & 261.0 & 130.5 \\
\hline
\end{tabular}

The necessary levels of the fuel consumption tax (NoVA) have been analyzed as third policy option. Currently the NoVA amounts to $4 \%$ of the purchase price for the cases under consideration. As shown in Table 6, the NoVA would need to be increased by up to $45 \%$ in order to sufficiently support EVs from 2011 onwards. Similarly to the $\mathrm{CO}_{2}$-tax, an increase in the NoVA as sole policy instrument is considered to be politically infeasible and it may cause adverse effects on the total automotive market.

Table 6: Required level of NoVA in \%

\begin{tabular}{rrrrrr} 
& 2011 & 2012 & 2013 & 2014 & 2015 \\
\hline NoVA & 45 & 40 & 35 & 30 & 0
\end{tabular}

\section{Concluding Remarks}

Several TCO have been calculated for EV and ICE. The BAU-scenario shows that EV shall be competitive with ICE in the year 2015 if no additional policy actions are taken. However, significant learning effects are assumed to decrease costs of electric cars. Such learning effects can be mainly triggered if policy makers sufficiently support research and development of new environmentally friendly vehicle technologies. The analysis shows that both CO2 and NoVA taxes, which increase the costs of ICE, have to be prohibitive to make electric cars competitive. Introducing such levels of taxes seems not politically feasible besides other adverse effects on the vehicle market. Therefore, up-front price support systems (e.g. direct financial support, exemption from registration tax, bonus/malus system, etc.) seem to be favorable over the taxation systems. These results are confirmed by literature. Even though cost disadvantages can be overcome by policy support instruments, technical limitations of EV such as limited range and relatively long charging times remain. In addition to closing the TCO gap between EV and ICE and to overcoming technical limitations, policy makers shall focus on providing infrastructures for a large-scale take-up of EV.

\section{References}

[1] EU Insight, Driving toward a more sustainable future, Issue No. 29, 2009. 
[2] S. Schmid, P. Mock, H. Friedrich, Welche Antriebstechnologien prägen die Mobilität in 25 Jahren, Zeitschrift für Energie Markt Wettbewerb, 4, 2010, pp.6-11.

[3] C. Thiel, A. Perujo, A. Mercier, Cost and $\mathrm{CO}_{2}$ aspects of future vehicle options in Europe under new energy policy scenarios, Energy Policy, 2010, pp. 7142-7151.

[4] J. Ogden, R. Williams, E. Larson, Societal lifecycle costs of cars with alternative fuels/engines, Energy Policy, 2004, pp. 7-27.

[5] C.E. Thomas, Fuel cell and battery electric vehicles compared, International Journal of Hydrogen Energy, 2009, pp. 6005-6020.

[6] F. Kley, M. Wietschel, D. Dallinger, Evaluation of European electric vehicle support schemes, Working Paper Sustainability and Innovation No. S 7/2010, Frauenhofer ISI, 2010.

[7] AEA Energy \& Environment, Hybrid Electric and Battery Electric Vehicles: Measures to Stimulate Uptake, Version 2, 2008.

[8] AEA, Market Outlook to 2022 for Battery Electric and Plug-in Hybrid Electric Cars, Issue 1, 2009.

[9] European Automobile Manufacturers’ Association (ACEA), Overview of Tax Incentives for Electric Vehicles in the EU, 2010.

[10]Joint Research Center, Well-To-Wheels analysis of future automotive fuels and powertrains in the European context, Version 3, 2008.

[11]OEAMTC, Zukünftige Elektrofahrzeuge, 2010.

[12] VW, Der Golf - Preise, Austattungen, Technische Daten, November 2010.

[13]K. Handa, H. Yoshida, Development of Next Generation Vehicle „i-MiEV“, Mitsubishi Motors Technical Review, No.19, 2007.

[14] The Boston Consulting Group, The Comeback of the Electric Car? How Real, How Soon, and What Must Happen Next, 2009.

[15] PricewaterhouseCoopers, Elektromobilität in Österreich, internal paper, 2010.

[16] McKinsey, Roads toward low-carbon energy future: Reducing CO2 emissions from passanger vehicles in the global road transportation system, 2009.

[17]Element Energy, Strategies for the uptake of electric vehicles and associated infrastructure implications, 2009.

[18]H. Hammer, S. Jagers, What is a fair $\mathrm{CO}_{2}$ tax increase? On fair emission reductions in the transport sector, Ecological Economics, 2007, pp. 377-387. 